\title{
A Needs Analysis of Instructional Materials on Methodology of Research Based on Scientific Publications for Special Education Master Program
}

\author{
Yuliyati, Budiyanto \& Endang Purbaningrum \\ Universitas Negeri Surabaya \\ Surabaya, Indonesia \\ yuliyati@unesa.ac.id
}

\begin{abstract}
The purpose of this study is to create instructional materials for Methodology of Research based on Scientific Publications for Special Education Master Program to support publications in accordance with the Standards of Higher Education that publish scientific work in international journals. Four-D Thiagarajan development research methods (Define, Design, Development, Dissemination) were implemented in 2 years. Data are collected by questionnaires, and interviews, observations, and documentation. Moreover, data are analyzed by interactive techniques. Define stage result showed that: (1) initial-final analysis: problem in scientific work publication of Special Education Master Program not complied yet to DGHE (Directorate General of Higher Education) standard; (2) learner analysis; (3) concept analysis; (4) instructional materials Research-based publication literature; (5) objective formulation: 15 theoretical and practical objectives are formulated, the focus of nationalinternational journal-publishing practice. The design stage produces a map of instructional materials and contents and physical book design. The product is an initial draft that requires refinement and further research.
\end{abstract}

Keywords-Instructional Materials; Research Methods; Scientific Publications; Special Education Master Program.

\section{INTRODUCTION}

Scientific publications are important in the academic world for the existence of the scientific world, certification of results of activities that meet the requirements of scientific, dissemination and archival, as well as a barometer of higher education research quality to be able to benefit the progress of the nation global competition, commercialization and downstream research results should be actualized through the synergy of higher education with economics. International publications are also an absolute prerequisite to world class university. In fact, Indonesia has the lower level of publication than Malaysia, Turkey, and China, in which Malaysia has published 1428 publications, while Indonesia has published only 522 publications. Thus, Ministry of Higher Education and Scientific Research (MHESR) encouraged to publish about 7-10 regulations that have boosted the scientific publication as of March 13, 2017 Indonesia's international publications are now at 11,675, this number is far compared to the year 2014 which is still at number 4,200 .

One such regulation is the stipulation of scientific publication as a requirement of graduation (Law of The Republic of Indonesia Number 44 Year 2015 on Higher Education) for the compulsory master program of scientific research publications in accredited national scientific journals or accepted in international journals. Scientific publication as a student graduation requirement has now been urged and become mandatory this is including: (1) Students of the Master Program must issue papers (research scientific works) in accredited scientific journals or be accepted in international journals; (2) Students of the Doctoral Program are obliged to publish papers in reputable international journals; and (3) Students of the Applied Doctoral Program must publish papers in accredited national journals or be accepted in international journals or; works presented or exhibited in international forums.

Five years of this policy has been implemented by universities, but most have not met the ideal criteria of Kemenristek-Dikti. In State University of Surabaya undergraduate students must have publications in the Journal of each Study Program, ISSN, while master and dotorate graduates are still just submitting. Successful publication is not an easy matter, it requires mastering the research methodology according to the scientific family, carrying out research, quality research results, article writing skills, understanding and mastery of publication practices. This requires continuous training and practice and publication action to the intended journal. Responding to this to improve the ranking of international publications, State University of Surabaya implement strategies (1) mentoring and training publications and incentives for successful publications in reputable indexed international journals such as Scopus. (2) Preparing and encouraging the publication of State University of Surabaya journals can be internationally accredited and indexed in reputable indexing institutions.

The publications of the students of Special Education Master Program are still merely on submitting. However, scientific of research still questioned because of the varied interference / obstacle of students with special need resulted 
in variability problems [1]. The special education research should be scientifically based and the methodology should be based on research questions [2]. Failure of publication among students in accredited journals nationally or in international journals due to the lack of accredited national journals (6-10 journals) that enable students to access, they also have to compete with Indonesian lecturers with waiting list ranging from 1-2 years. In addition, publications in international journals have not been scheduled, practiced, tried because it requires a large cost. Whereas the ultimatum MHESR that the end of tolerance of publication as a graduation requirement on December 22, 2017. This means that in 2018, graduation students must meet the requirements of the higher education.

The main problem of the failure of publication is the quality of research paper that is rooted in the courses that foster this skill that is the subject of research methodology and seminar. The specificity of the special education is very complex as the trend of the world development of the $21 \mathrm{st}$ century. To be able to examine correctly and accurate results required the basics of scientific research as well as the mastery of special education scientific substance. This is important for the development of knowledge and the existence of special education scientific.

Instructional material for research methodology course of Special Education Master Program is 60\% theoretical because of the diverse inputs of scientific fields and most have not understood the specificity of special research, while $40 \%$ practice with the task of preparing the thesis proposal and articles. Furthermore, seminar courses are not scheduled within the framework of Special Education Master Program curriculum. This indicates that the subject matter of the special education master research methodology has not yet led to Scientific publications, which are the demands of Higher Education as the Ministry of Scientific Research (MSR) that scientific research and publication is an important element in education. Scientific research and publications are like two sides of a coin that can not be separated. Unpublished scientific research results will only be a pile of documents that fill the corner of the library space. The results of scientific research in higher education should be published, so that research has more meaning and contribute to the spread of science. Therefore, efforts to improve instructional materials research methodology and seminar courses designed to achieve the target of scientific publications both national and international scientific publications. for the success of international publications utilized books and articles on publication success.

Based on this explanation, the development of teaching materials for scientific publication-based on research methodology course needs to be carried out to explore existing problems and constraints and find solutions to these problems, produce products of research methodology teaching materials that are intended to improve the scientific publications of Special Eduction Master Program students through lectures and assignments structured direct practice of scientific publications.
In this regard, this study aims to produce teaching materials for publication-based on research methodology course of Special Education Master Program. Specifically, the products include: Textbooks of Special Education Research Methods based on scientific publications referring to the Semester Learning Plan.

\section{METHOD}

This research is a research development $(\mathrm{R} \& \mathrm{D})$ which is done in two stages with Four-D [3] model, covering define, design, develop, and disseminate. Stage 1 definedesign, determining data base problems and designing / mapping of instructional materials. Stage 2 developdisseminate, the map of the instructional materials developed into a product draft, followed by expert test. Data were analyzed by percentage technique. The result is the basis of revision 1 for the limited test and field test. Field trials with one-group design and action research design Mahmud and Priatna [4] to illustrate the natural context of product implementation. Data were collected by questionnaire, test, observation, interview, recording. Statistical analysis of non parametric statistics interactive flow data analysis were applied, including data reduction, data display, verification, and conclusions [5]. Data validity were checked with triangulation technique. Experimental test analysis results are used for revision. Next product is revised and refined. Dissemination, revised and refined products are disseminated to a wide range through product distribution and scientific publications.

The Define-Design phase carried out in the first year includes: (1) front end analysis, (2) student analysis, (3) concept analysis (4) task analysis, and (5) formulation of objectives as shown in figure 1 . The front end analysis aims to raise and determine the basic problems faced by students in facing the challenges The analysis phase of students' studies focuses on the characteristics of Special Eduction Master Program students related to the development design of teaching materials for research methodology. This is including academic abilities, cognitive development, individual skills - social, media, mastery of formats and appropriate language in preparing teaching materials.

Concept analysis is focused on mapping the mastery of material to achieve competencies in attitudes, knowledge, and general-specific skills in accordance with scientific publications for masters programs. In this case scientific publications in an accredited National Journal of concern in addition to International journals must also be understood.

Task Analysis to identify key skills in research tasks focused on practice (preparation of proposals, reports, articles, access to journals and publications that must be mastered by Special Eduction Master Program students. In this regard a curriculum analysis and problem analysis of related student mastery is carried out by research methodology courses.

The purpose formulation is intended to operationalize the competencies that have been mapped in the concept analysis followed up with a formulation of objectives that are in line 
with the needs of students in an effort to master the publication-based research methodology.

The Design Stage produces a teaching material map for Special Education Research Methodology / and product of textbook draft that requires further research to improve it.

Figure 1: Year 1 Define-Design- Development Stage

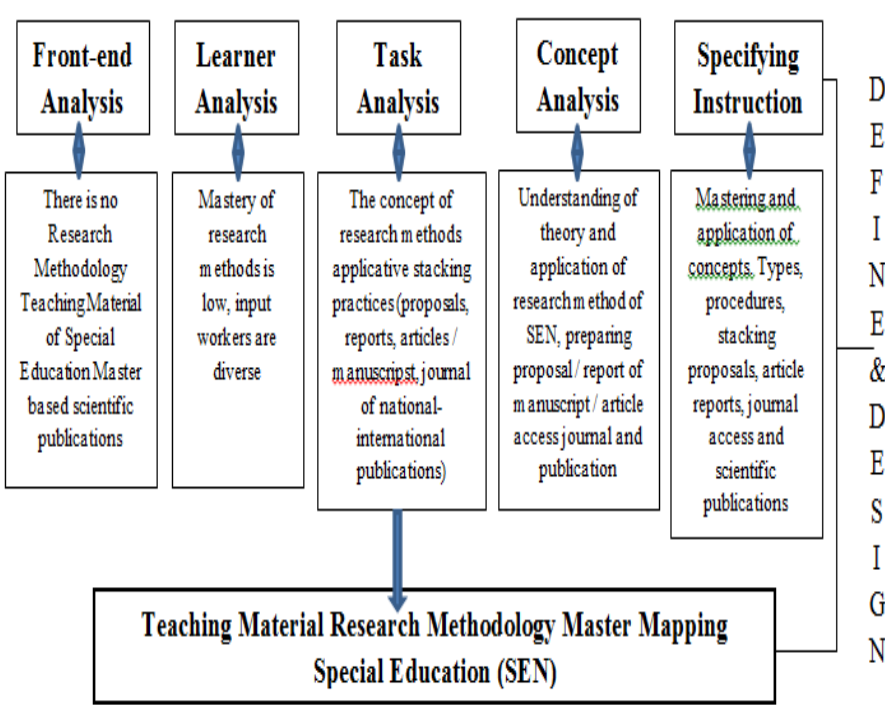

The research result on the instructional material of methodology of research based on the scientific-publication of year 1 is a description of the results of the development process of Define-Design stage. Define stage includes five activities shown in table 1 . The findings of front-end analysis of the absence of typical instructional materials of special education shows that the development of textbook is very important to help students understand the material and develop their knowledge, moreover textbook can also function as a preparation for synthesis and analysis in conducting research. In line with this, UNESCO pointed out that there are three factors that are considered dominant for the non-success of the learner / lecture, one of which is the absence of instructional material, especially textbooks, which, if any, is inadequate. Failed publications in accredited journals require a publication strategy in the form of mentoring and training of publications and incentives if successful publications to Scopus-index journals.

The findings of various learner analyzes indicate the importance of the instructional material for methodology of research on Special Education. The findings of Yeoman and Zamorski [6] show that lectures on research skills have an effect on development of students skills, especially the gradual practice exercises, improves the understanding of the environment and the research process, the literature, the confidence in scientific writing, alongside with presents the scientific materials.
TABLE I. RESULT OF THE RESEARCH

\begin{tabular}{|c|c|c|}
\hline No & $\begin{array}{l}\text { R\&D } \\
\text { Define } \\
\text { Stage }\end{array}$ & Results \\
\hline 1 & $\begin{array}{l}\text { Front-end } \\
\text { analysis }\end{array}$ & $\begin{array}{l}\text { Instructional materials on Research } \\
\text { methodology of research based on } \\
\text { publication for Special Education } \\
\text { Master Program as per the students } \\
\text { with special needs characteristics } \\
\text { research is not yet available. } \\
\text { Scientific publications to accredited } \\
\text { or international journals have not } \\
\text { succeeded }\end{array}$ \\
\hline 2. & $\begin{array}{l}\text { Learner } \\
\text { analysis }\end{array}$ & $\begin{array}{l}\text { Master students of Special Education } \\
\text { have high motivation, working in } \\
\text { special education field, independent } \\
\text { cost, bachelor qualified varied, range } \\
\text { of age } 22-45 \text { years. The knowledge of } \\
\text { special education is diverse. }\end{array}$ \\
\hline 3 & $\begin{array}{l}\text { Task } \\
\text { analysis }\end{array}$ & $\begin{array}{l}\text { The lectures tasks on mastery } \\
\text { applicative competence in the } \\
\text { submission of proposals and articles is } \\
\text { adequate, sufficient and inadequate } \\
\text { competence. There are errors in almost } \\
\text { every grain of the topic selection } \\
\text { thesis, the title, the formulation of the } \\
\text { problem, the purpose of the term } \\
\text { explanation, the usefulness of the } \\
\text { research, the theoretical framework, } \\
\text { the study of the literature, the relevant } \\
\text { research, and the hypothesis. }\end{array}$ \\
\hline 4 & $\begin{array}{l}\text { Concept } \\
\text { Analysis }\end{array}$ & $\begin{array}{l}\text { The main concepts of instructional } \\
\text { materials on research methodology } \\
\text { course are mainly implementation. } \\
\text { Theories as the basis of practice, } \\
\text { prepare a proposal to conduct research, } \\
\text { prepare reports and articles, practice } \\
\text { training and publication actions. The } \\
\text { concepts as a basis for determining the } \\
\text { type and amount of instructional } \\
\text { materials in line with the standards of } \\
\text { INQF, knowledge competence, } \\
\text { attitude, competence and skills with } \\
\text { the source the latest trend material } \\
\text { from inside and overseas. }\end{array}$ \\
\hline 5 & $\begin{array}{l}\text { Specifying } \\
\text { instruction } \\
\text { al } \\
\text { objectives) }\end{array}$ & $\begin{array}{l}\text { The objective formulation of } \\
\text { objective-specific objectives of the } \\
\text { task analysis and concept analysis } \\
\text { findings are } 13 \text { general formula that } \\
\text { can be specified. }\end{array}$ \\
\hline
\end{tabular}


Essentially in the development model one of the important things to be considered is expressing an understanding of the learners characteristics $[3,7,8]$.

The findings of an analiyical task as many of the errors of the practice work are in line with the opinion of Shenton [9] that common mistakes that occur in proposals and research reports, namely: write errors, language errors, content errors, error analysis, mistranslation of analysis results, and conclusions. About the failure of the publication shows the importance of successful article and publication training. This needs continuous structured and systematically straightforward practice training and hard work. Tips in Writing Your Journal Article in 12 Weeks: A Guide to Academic

Findings of concept analysis that this implementative material is in line with Creswell [10] material on educational research. Important research resources are characterized by special education [11]. (5) findings on specifying instructional objectives that are interrelated with previous material. According to Thiagarajan [3] formulation of objectives is importantbecause it is useful to summarize the results of concept analysis and task analysis to determine the behavior of the object of research. Research involves interrelated activities rather than the application of separate concepts and ideas [10].

The findings of the design/instructional materials design stage are the instructional materials map and the textbook design obtained from the summary of the define stage and the design activities including, the test grille, the establishment of print media for product development, the format of the textbook products, and the initial draft of the materials / and Book design. Content and physical book product in the form of Draft. This activity as the statement [3] that the design stage aims to design instructional materials. The four steps to be taken at this stage are: (1) the compilation of the test standard (criterion-test construction), (2) media selection appropriate to the characteristics of instructional materials and learning objectives, (3) format selection, which examines the existing instructional material formats and specifies the format of the instructional material to be developed, (4) makes the initial design according to the selected format.

\section{CONCLUSION}

The conclusion of the research in Year 1 in the Define-Design stage is the description of the development process, covering the activity (1) front end analysis found the problem that there is no instructional material on methodology research based on the publication of scientific in special education master program; (2) the result of learner analysis that students of special education vary their bachelor qualifications. Generally they work in special education as and have high motivation to study; (3) results of concept analysis that the required research methodology concepts are implement, especially for the preparation of proposals in the effort of preparation of comprehensive examination, preparation of reports, compilation of articles, access of journals, accredited national scientific publications and international journals (4) in the task of the research methodology specially preparing the thesis proposal indicates many misconceptions on the elements of the thesis proposal, and (5) the formulation of the objectives produces 15 main items by considering the material of the previous year's methodology with additional material as required, particularly with respect to the preparation of the articles and scientific publications The design stage produced a map of instructional materials (initial design) in the form of map / skeletal material, and designed books.

\section{RECOMMENDATION}

Based on the previous conclusions, the following recommendations can be given:

- Further research is needed with wider population.

- The need for developing this model in other areas.

- It is possible to use another of data analysis techniques and testing the validity of other data.

\section{REFERENCES}

[1] D. C. Berliner, "Comment: Educational research: The hardest science of all," Educational researcher, vol. 31, pp. 18-20, 2002.

[2] S. L. Odom, E. Brantlinger, R. Gersten, R. H. Horner, B. Thompson, and K. R. Harris, "Research in special education: Scientific methods and evidence-based practices," Exceptional children, vol. 71, pp. 137148,2005

[3] S. Thiagarajan, "Instructional development for training teachers of exceptional children: A sourcebook," 1974

[4] M. Mahmud and T. Priatna, "Penelitian tindakan kelas," ed: Tsabita, 2008.

[5] M. B. Miles, A. M. Huberman, and J. Saldana, Qualitative data analysis: Sage, 2013.

[6] K. H. Yeoman and B. Zamorski, "Investigating the impact on skill development of an undergraduate scientific research skills course," Bioscience Education, vol. 11, pp. 1-14, 2008.

[7] M. D. Gall, W. R. Borg, and J. P. Gall, Educational research: An introduction: Longman Publishing, 1996.

[8] W. Dick, L. Carey, and J. O. Carey, "The systematic design of instruction," 2005.

[9] A. K. Shenton, "Strategies for ensuring trustworthiness in qualitative research projects," Education for information, vol. 22, pp. 63-75, 2004

[10] J. W. Creswell, "Research design," Qualitative and Quantitative Approach. Thousand Oaks: SagePublications, 1996.

[11]J. Sunanto, K. Takeuchi, and H. Nakata, "Penelitian dengan subjek tunggal," Bandung: UPI Pres, 2006. 